UDC 005.73:005.1

JEL Classification: G31, L62

DOI 10.26906/eip.2019.2(73).1627

\title{
THE MODEL OF CORPORATE CULTURE IN THE CONTEXT OF STRATEGIC INITIATIVES OF MACHINE-BUILDING ENTERPRISES
}

\author{
Olena Androsova*, PhD, Assistant Professor. \\ National University «Zaporizhzhia Polytechnic»
}

* ORCID 0000-0002-2727-2474

(C) Androsova O., 2019.

Стаття отримана редакиією 30.05.2019 p.

The article was received by editorial board on 30.05.2019

Introduction - Increasing the effectiveness of corporate culture in machine-building enterprises is possible due to the introduction of new strategic initiatives, analytical procedures, specific methods, which depend on the strategic and financial attractiveness of industries mastered by machine-building enterprises. Corporate culture is here as the main mechanism for practical improvement of efficiency at the enterprises of mechanical engineering. It affects the workers' motivation, the attractiveness of the enterprise, the morality of each worker, the business reputation, the productivity and efficiency of labor activity, the creative potential of the workers, the formation of a positive image of the enterprises of mechanical engineering. Therefore, in order to increase efficiency at the machine-building enterprises, a model of corporate culture in the implementation of the strategy is required.

An overview of the main sources of research and publications. This issue was studied by leading scientists and economists, namely: Antoniuk A.A., Shmyhol N.M. [1], Asaul A.M. [2], Beloshapka V.A. [3] Khimych I.H. [4], Gallo P, Gonos J. [5], Mulhouse Ya., Kostya M. [6], Setiawan K., Santos B. [7], Stojanovic A.V., Nedelko Z. [8]. There are many models of corporate culture. Leading experts suggest interesting examples to be considered, but it is managers who have to decide whether the proposed model will be suitable for one or another machine-building enterprise or not. It is the model of corporate culture in the context of strategic initiatives of machine-building enterprises that requires more thorough research.

Setting targets. The following tasks were set: to investigate the responsibility mechanism of managers of corporate business portfolio, to develop measures to be taken in case of a threat of a reduced efficiency on the machine-building enterprises, to develop a model of corporate culture in the implementation of the strategy of machine-building enterprises.

Main material and results. New strategic initiatives that improve the overall efficiency of mechanical engineering enterprises play an important role in improving the efficiency of machine building enterprises, and the main ones are analytical procedures, the methods of which depend on the strategic and financial attractiveness of the industries that are mastered by the machine-building enterprises. Managers should constantly study corporate business portfolios, as well as provide a conclusion on the following indicators: the number of divisions of the enterprise in attractive industries; the number of units in the mature and stagnant industries, lowering the indicators that can negatively affect the overall productivity of the enterprise; dependence of units on factors of seasonality and periodicity, on the appearance of new technologies; the number of uncertain prospects; number of units with medium or low level of competitiveness; strategic match between the divisions of the enterprise; presence in the portfolio of unnecessary units; resource correspondence between divisions; the ratio of "dairy cows and leeches"; ability of key divisions of the enterprise to form a significant part of profits and cash receipts; the ability of the current business portfolio to provide the company with a solid position in the future.

Qualitative analysis of the business portfolio allows to identify in time whether the company needs to separate the units and buy others, to restructure the portfolio, to constantly review the resource allocation policy, or to focus on the realization of their existing capabilities of an efficient enterprise in the modern environment.

Such analysis of the strategic and financial attractiveness of a corporate business portfolio should indicate whether the company is able to achieve the planned performance at the current stock and resource base. In case the analysis is confirmed no changes in the enterprise strategy are required. As a result of the 
threat of reduced efficiency, managers should immediately take the following measures:

- to change the strategic plans of some or all of the divisions of the enterprise. To implement new initiatives in order to improve the performance of these units, if necessary, supported by resources beyond the plan. As practice shows, short-term performance improvements at the expense of the entire enterprise are very unreliable and do not provide sustainable financial growth in the long run. Short-term improvement measures that do not respond to the long-term course should be treated with great caution;

- enrollment of the new divisions of the enterprise into a business portfolio. It is the increase in overall efficiency through the acquisition or creation of new enterprises that poses the following issues to the management, namely: what businesses to buy - family or non-related; what the acquisition volumes should be; how new divisions will integrate into the structure of the enterprise; what characteristics should be owned by the acquired enterprises; whether it is possible to finance new acquisitions without the funding reduction of the existing divisions. Enrollment in the business portfolio of new enterprises is the main strategic way to stabilize the decline in productivity of machine-building enterprises;

- separation of low-profit or loss-making divisions. The main candidates for the separation include enterprises with weak competitive positions in relatively unattractive industries that do not strategically match other departments and/or with insufficient resources. Funds received from sales of units can be directed to new acquisitions, repayment of current debts or to strengthen the positions of the remaining units;

- gaining increase efficiency through the creation of alliances. In general, increasing efficiency helps to create alliances with local or foreign partners, suppliers, consumers or interest groups. Mutually beneficial agreements on sharing resources with suppliers, interested competitors or producers of additional goods, as well as joint beneficial initiatives help to increase the competitiveness and efficiency of the enterprise. The timely creation or support of political groups for lobbying for enterprise-friendly solutions for import-export, tax rates is an effective means to improve the situation of the enterprise;

- timely updating of the resource base of the enterprise. Such an increase in efficiency occurs as a result of creating new resources that will allow individual units of the enterprise to catch up with competitors or outstrip them and get a steady competitive edge. Special role is played by corporate management, which helps to increase the value of shares by coordinating the development of advanced technologies and competently placing new resources among the divisions of the enterprise;

- reduction of the planned indicators of corporate efficiency. The planned performance indicators are not consistent with the downturn in one or more key industries, as well as unfavorable market conditions. When defining goals, unnecessary ambition gives a similar result. In this case, it is necessary to bring the planned indicators closer to reality. But the review of the targets is the last resort and should be used when all other means have been exhausted.

In order for the corporate culture in the machine-building enterprises to be effective, it is necessary to implement the strategy of the machine-building enterprises. To do this, we propose a model of corporate culture of the machine-building enterprises, which consists of six strategy blocks (Figure 1), namely:

- the strategy of financial and economic activity includes the following components: providing business activity, ensuring financial stability, ensuring solvency, providing competitiveness, reducing the cost price;

- the strategy of the enterprise development is based on high moral qualities of senior managers, high moral qualities of workers, gender strategy, personnel strategy, revision of cultural values;

- the strategy of producing new products contains the following elements: the identification of the idea of enterprise research, the transformation of the organizational structure, reorganization of the sales service, expanding the provision of services, increasing attention to the demand, reducing staff without dismissal;

- the strategy of entering new markets includes: the identification of the idea prompted by the market; identification of ideas that derive from the benefits of the enterprise; the withdrawal of the unpromising ideas, the identification of the idea of imitation of other enterprises;

- the resource strategy takes into account: the strategy of ensuring the competitiveness of products; scale of production strategy; development of partnership relations with enterprises-competitors; other factors;

- information strategy is formed by the following components: information analysis, international situation, relevant government policy, competitiveness of enterprises in the world market.

At the machine-building enterprises, the proposed strategy will work if it complies with the following principles for the development of a successful strategy:

- Strategic actions that strengthen the competitive position of machine-building enterprises should be prioritized in the long run. Only a strong competitive position for many years brings fruitful results, rather 
than good quarterly and annual projected profit and sales volumes. Shareholders always put long-term strategic initiatives ahead of short-term financial performance. Long-term strategic initiatives considerably strengthen long-term competitive positions of the machine-building enterprises and give them new competitive advantages. In order to obtain high profit in the long-term perspective, it is necessary to consistently implement a strategy aimed at strengthening of the long-term competition.

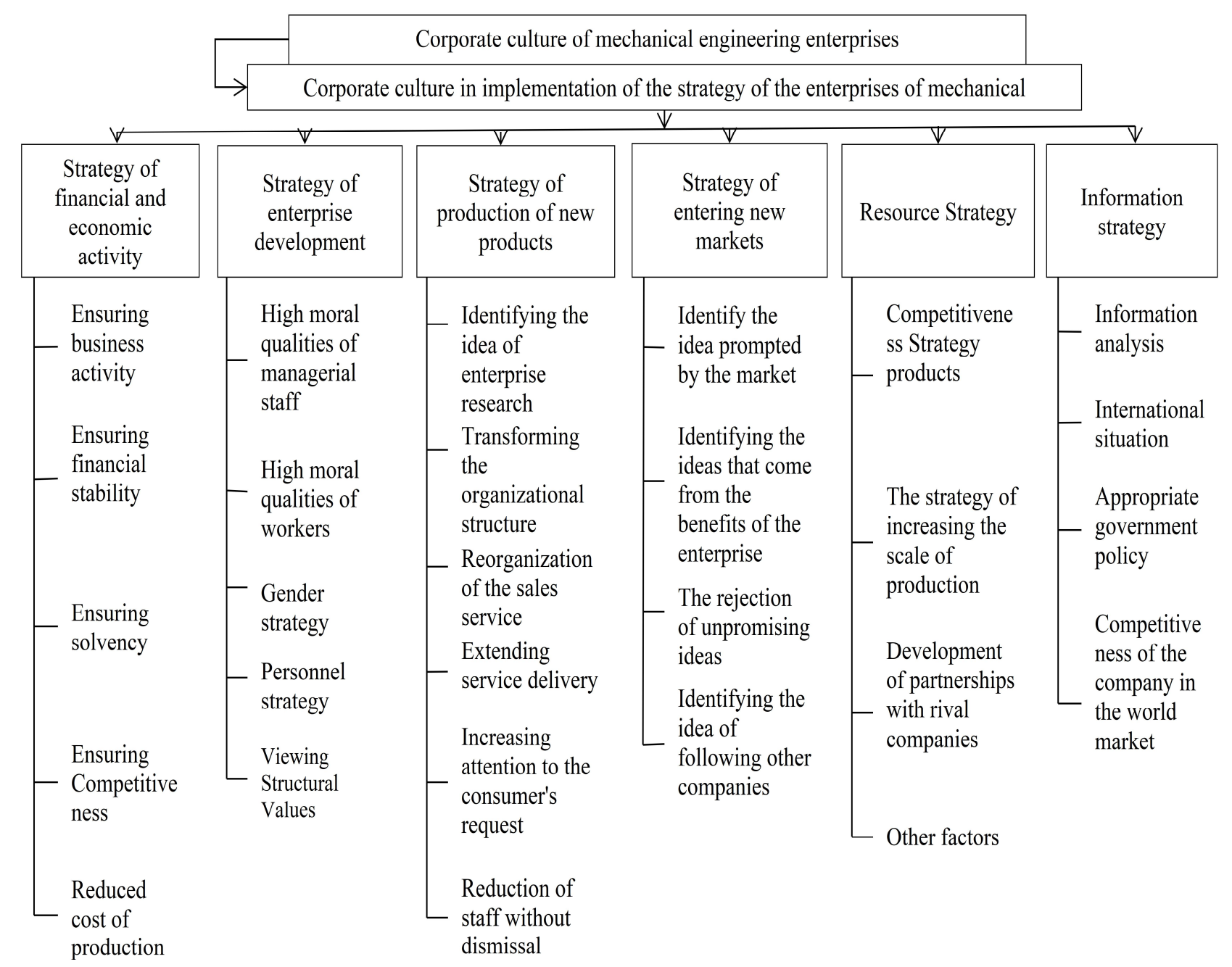

\section{Fig. 1. Model of corporate culture in the implementation of the strategy of the enterprises of mechanical engineering [developed by the author]}

It is necessary to react quickly to the changing market situation and consumer needs, technological innovations, new initiatives of competitors. The enterprise is in a disadvantageous situation in case of a delayed or inadequate reaction and acts as a catching-up. To do this, it's best to timely adapt the top-priority strategy to new circumstances, although this strategy has its advantages. The long-term strategic intentions of machine building enterprises to improve quality or reach the lowest possible costs should be considered in the same aspirations of competitors, as well as the needs and expectations of buyers. Ideal quality or minimal costs should not be an end in itself.

Investing funds must be made in creating sustainable competitive advantages at the machine-building enterprises - this is the only reliable way to achieve profit above the industry average. An enterprise must pursue an aggressive offensive strategy for gaining competitive advantage and an aggressive defense strategy for its maintenance.

Need to avoid strategies designed to succeed only in favorable conditions. It is necessary to think about possible actions of competitors and prepare for the most adverse events in the market. A good strategy works reliably and provides good results even in harsh conditions.

Adequate assessment of the abilities and ambitions of competitors is necessary. Competitors are 
dangerous when they have nothing to lose, or their well-being is threatened.

It should be remembered that attacking weak competitors is much safer and more profitable than to attack strong ones. The attack on a large and ready-to-defeat competitor can lead to defeat if the attacker company does not have strong financial resources and good competitive advantages.

You do not need to lower prices without having a tangible cost advantage. Only a spending leader is able to lead a long price war.

It is necessary to achieve maximum separation from competitors for the quality of goods and services or consumer properties. Buyers may not notice slight differences between the products of different companies.

It is necessary to avoid intermediate strategies that arise when trying to simultaneously pursue two opposing strategies. Compromise strategies rarely give competitive advantages or an excellent competitive position to the machine-building enterprises - the skillfully implemented strategy of optimal combination of price and quality is an exception.

If the company chooses a compromise strategy, it achieves the average cost level, the average degree of product differentiation, the average reputation image, and occupy the middle level in the market with insignificant chances to break into the leaders.

Progressive actions to capture part of the market share result in more fierce competition, especially when the industry is characterized by a larger volume of inventories or excess production capacity. Therefore, aggressive actions to capture the part of competitor market lead to aggravation of the situation in the industry, price wars and damage to all enterprises.

Conclusions. The model of corporate culture in the context of corporate initiatives is developed taking into account the strategy of financial and economic activity, development, entry into new markets, effective information strategy that ensures business activity, financial stability, solvency, competitiveness of enterprises and provides high moral qualities of managers and workers; promotes gender strategy and moral values, as well as seeks to identify and consolidate the strengths of the enterprise in the domestic and global markets.

\section{REFERENCES:}

1. Antoniuk A., \& Shmyhol N. (2012) Otsinyuvannia ekonomichnoi efektyvnosti upravlinnia korporatyvnoyiu kulturoiu [Evaluation of the economic efficiency of corporate culture management] / State and regions. Series: Economics and Business. - 2012. - No. 4. - P. 27-31.

2. Asaul A. M. \& Koval O. S. (2012) Osnovni napriamy pidvyshchennia yakosti ta efektyvnosti rozrobky i pryinyattia upravlinskykh rishen u pidpryiemnytskykh strukturakh [Main directions of improvement of quality and efficiency of development and acceptance of managerial decisions in business structures] / Economy of Ukraine. - 2012. - No. 11 (612), November. - P. 29-37.

3. Beloshapka V. \& Kulik Yu. (2011) Instrumental'nyye kompetentsii menedzhera pri formirovanii rynochnoy korporativnoy kul'tury. [Instrumental competencies of the manager in the formation of a market corporate culture] / Stock market. - 2011. - No. 11 March. - P. 20-24.

4. Khimych I.H. (2010) Models of formation of corporate culture for machine-building enterprises / State and regions. Series: Economics and Business. - 2010. - No. 2. - P. 218-223.

5. Gallo P. Corporate culture typology model with regard to organizational structure / P. Gallo, J. Gonos. - 2014. - № 12 (162). - P. 304-310.

6. Mulhouse Y. \& Kostya M. (2018) Pozitivnoye liderstvo na korporativnom urovne: kak vystroit' vyigryshnuyu kul'turu: [Positive leadership at the corporate level: how to build a winning culture:] chapter from the book "Inspiring Leader. Team. Meanings. Energy." / Banking Management. - 2018. - № 1. - p. 2934.

7. Setiawan K. (2017) Influence of managerial leadership, corporate culture and ERP implementation on corporate performance / K. Setiawan, B. Santoso. - 2017. - № 3 (189). - P. 253-259.

8. Stojanovic, Aleksic V. (2013) Is it necessary to change organizational culture? Slovenianserbian experience A. V. Stojanovic, Z. Nedelko, V. Domanovic. - 2013. - № 2. - P. 354-362.

9. Thompson Jr., Arthur, D., Strickland III, L., J. (2006) Strategic management: concepts and 
situations for analysis, 12th edition: Trans. from English - M .: Publishing House "Williams", 2006. - 928 p. : il. - Parat tit. English

10. Andrushkyk B.M. (2011) Korporatyvne upravlinnia: navchalnyi posibnyk. [Corporate governance: tutorial]. - K.: Condor, 2011. - 582 p.

11. Andrushkyk B.M. (2011) Korporatyvne upravlinnya [Corporate Governance:] Textbook / Andrushkov B.M., Chernichintsev S.P. - K.: Condor, $2011-528$ p.

12. Zakharchyn H.M., Liubomudrova N.P., Vinnychuk R.O., Smolinska N.V. (2011) Korporatyvna kultura [Corporate culture] / Tutorial. - Lviv, 2011 - 317 pp.

13. Svatiuk O. R. (2015) Infrastruktura korporatyvnoho seredovyshcha: zovnishni ta vnutrishni strukturni elementy [Infrastructure of the corporate environment: external and internal structural elements] / "Lvivska Polytechnika" National University. Herald.: Collection of Scientific Works № 819. Management and entrepreneurship in Ukraine: stages of formation and problems of development. - Lviv, 2015. - P. 8291.

14. Sydorko I. (2017) Formuvannia pozytyvnoi korporatyvnoi kultury orhanizatsiy [Formation of positive corporate culture of organizations] / Measuring technique and metrology: interdepartmental sciences: collection. Issue 78. - Lviv, 2017. - P. 118-123.

15. Strychalska-Rudzewicz A. Determinants of organizational culture that influence innovation. The case of production companies in Poland / Lviv Polytechnic National University. Herald.: Collection of Scientific Works No. 779. Problems of Economics and Management. -- Lviv, 2014. - P. 98-105.

\section{УДК 005.73:005.1}

JEL: G31, L62

Андросова Олена Федорівна, кандидат економічних наук, доцент. Національний університет «Запорізька політехніка». Модель корпоративної культури в розрізі стратегічних ініціатив підприємств машинобудування. Подано нові стратегічні ініціативи для підвищення ефективності на підприємствах машинобудування, які $\epsilon$ основою для стратегічного поліпшення загальної ефективності підприємств машинобудування, а головними в них виступають аналітичні процедури, конкретні методики яких залежать від стратегічної і фінансової привабливості галузей, освоєних підприємствами. Доведено, що менеджери-управлінці повинні постійно вивчати корпоративний бізнес-портфель та надавати висновки за окремими показниками: за кількістю підрозділів підприємства в привабливих галузях, за кількістю підрозділів у зрілих і застійних галузях; зниження показників, котрі можуть негативно впливати на загальну продуктивність підприємства; залежність підрозділів від факторів сезонності і циклічності, від появи нових технологій; кількість підрозділів 3 невизначеними перспективами; стратегічна відповідність між підрозділами підприємства; наявність портфелів непотрібних підрозділів; ресурсна відповідність між підрозділами. Здійснювати якісний аналіз бізнес-портфеля, проводити реструктуризацію портфеля, постійно переглядати політику розподілу ресурсів. Виявлено, що аналіз стратегічної і фінансової привабливості корпоративного бізнес-портфеля повинен показувати, чи здатне підприємство досягти запланованих показників при поточному складі та ресурсній базі. Зміни стратегії підприємства не потрібні, якщо цей аналіз підтвердиться. Розроблено заходи, які необхідно вжити в результаті існування загрози зниження ефективності. 3'ясовано, щоб корпоративна культура на підприємствах машинобудування була ефективною, необхідно реалізувати стратегію підприємств машинобудування. Запропоновано модель корпоративної культури підприємств машинобудування в розрізі стратегій, котра складається з шести блоків стратегій. Установлено, що для того, щоб запропонована стратегія працювала на підприємствах машинобудування, вона повинна відповідати принципам розроблення успішної стратегії. У результаті дослідження сформовано принципи успішної стратегії.

Ключові слова: стратегія, корпоративна культура, стратегічні ініціативи, модель корпоративної культури, корпоративний бізнес-портфель. 
UDC 005.73:005.1

JEL: G31, L62

Androsova Olena, $\mathrm{PhD}$, Assistant Professor. National University «Zaporizhzhia Polytechnic». The Model of Corporate Culture in the Context of Strategic Initiatives of Machine-Building Enterprises. The article presents new strategic initiatives for improving the efficiency of the machinebuilding enterprises, which are the basis for the strategic improvement of the overall efficiency of the machine-building enterprises, and the main ones of them are analytical procedures, the specific methods of which depend on the strategic and financial attractiveness of the industries developed by the enterprises. It is proved that managers should constantly study the corporate business portfolio and provide conclusions based on the single indicators: the number of enterprise divisions in attractive industries, the number of units in mature and stagnant industries; reduction of indicators that can negatively affect the overall productivity of the enterprise; the units dependence on factors of seasonality and periodicity, on the appearance of new technologies; the number of uncertain prospects; strategic match between the divisions of the enterprise; availability of portfolios of unnecessary units; resource matching between divisions. Managers have to carry out a qualitative analysis of the business portfolio, restructure the portfolio, and constantly review the resource allocation policy. It has been revealed that the analysis of strategic and financial attractiveness of corporate business portfolio should indicate whether the company is able to achieve the planned indicators in the current composition and resource base. Enterprise strategy changes are not required in case this analysis is confirmed. The measures to be taken in case of the threat of reduced efficiency have been developed. It has been established that in order the corporate culture at the machine-building enterprises were effective, it is necessary to implement the strategy of the machinebuilding enterprises, which consists of six strategy blocks. It has been established that in order for the proposed strategy to work at the machine-building enterprises, it must be in line with the principles of developing a successful strategy. As a result of the research, the principles of a successful strategy have been formulated.

Key words: strategy, corporate culture, strategic initiatives, corporate culture model, corporate business portfolio.
УДК 005.73:005.1

JEL: G31, L62

Андросова Елена Федоровна, кандидат экономических наук, доцент. Национальный университет «Запорожская политехника». Модель корпоративной культуры в разрезе стратегических инициатив предприятий машиностроения. Представлены новые стратегические инициативы для повышения эффективности на предприятиях машиностроения, которые являются основой для стратегического улучшения общей эффективности предприятий машиностроения, а главными в них выступают аналитические процедуры, конкретные методики которих зависят от стратегической и финансовой привлекательности отраслей, освоенных предприятиями. Доказано, что менеджерыуправленцы должны постоянно изучать корпоративный бизнес-портфель и предоставлять выводы по отдельным показателям: по количеству подразделений предприятия в привлекательных отраслях, по количеству подразделений в зрелых и застойных отраслях; снижение показателей, которые могут негативно влиять на общую производительность предприятия; зависимость подразделений от факторов сезонности и цикличности, от появления новых технологий; количество подразделений c неопределенными перспективами; стратегическое соответствие между подразделениями предприятия; наличие портфелей ненужных подразделений; ресурсное соответствие между подразделениями. Осуществлять качественный анализ бизнес-портфеля, проводить реструктуризацию портфеля, постоянно пересматривать политику распределения ресурсов. Выявлено, что анализ стратегической и финансовой привлекательности корпоративного бизнеспортфеля должен показывать, способно ли предприятие достичь запланированных показателей при текущем составе и ресурсной базе. Изменять стратегии предприятия не надо, если данный анализ подтвердится. Разработаны мероприятия, которые необходимо принять в результате существования угрозы снижения эффективности. Выяснено, чтобы корпоративная культура на предприятиях машиностроения была эффективной, необходимо реализовать стратегию предприятий машиностроения. Предложена модель корпоративной культуры предприятий машиностроения в разрезе стратегий, которая состоит из шести блоков стратегий. Установлено, что для того, чтобы предложенная стратегия работала на предприятиях машиностроения, она должна отвечать принципам разработки успешной стратегии. В результате исследования сформированы принципы успешной стратегии.

Ключевые слова: стратегия, корпоративная культура, стратегические инициативы, модель корпоративной культуры, корпоративный бизнеспортфель. 